\title{
PERBEDAAN KETERAMPILAN PROSES SAINS (KPS) SISWA MENGGUNAKAN MODEL PEMBELAJARAN INQUIRY TRAINING DAN PEMBELAJARAN KONVENSIONAL PADA MATERI POKOK ELASTISITAS DAN HUKUM HOOKE DI SMA
}

\author{
Yul Ifda Tanjung1), Zafira Rahmatilla2) \\ 1)Dosen Program Studi Pendidikan Fisika, FMIPA, Universitas Negeri Medan, Medan, Indonesia \\ 2)Mahasiswa Program Studi Pendidikan Fisika, FMIPA, Universitas Negeri Medan, Medan, Indonesia \\ Corresponding author: Yuf Ifda Tanjung \\ E-mail : zafirarahmatillah@gmail.com
}

Diterima 29 April 2020, Disetujui 5 Mei 2020

\begin{abstract}
ABSTRAK
Penelitian ini bertujuan untuk mengetahui adanya perbedaan Keterampilan Proces Sains (KPS) siswa menggunakan model pembelajaran inquiry training dan pembelajaran konvensional mengenai materi pokok elastisitas dan hukum Hooke di SMA. Jenis Penelitian ini adalah quasi-experiment dengan desain two groups pretest-posttest. Populasi penelitian ini adalah seluruh siswa kelas XI MIPA SMA Negeri 5 Medan. Sampel diambil dengan teknik purposive sampling yang terdiri dari dua kelompok yaitu kelompok eksperimen dan kelompok kontrol. Teknik pengumpulan data dilakukan dengan tes dan observasi aktivitas KPS siswa. Data dalam penelitian ini dianalisis menggunakan pengujian hipotesis uji t. Hasil penelitian menunjukkan adanya perbedaan KPS yang signifikan antara penerapan menggunakan model pembelajaran inquiry training dibandingkan pembelajaran konvensional dengan nilai sig. 0,000 pada taraf signifikan 0,05. Berdasarkan hasil uji $\mathrm{N}$-Gain Score dengan penerapan model pembelajaran inquiry training lebih tinggi dalam meningkatkan KPS siswa sebesar 0,70 dalam kategori tinggi dibandingkan KPS siswa dengan penerapan pembelajaran konvensional sebesar 0,59 dalam kategori sedang.
\end{abstract}

Kata kunci: keterampilan proses sains; model pembelajaran inquiry training.

\begin{abstract}
This study aims to determine the differences in Science Proses Skills (SPS) of students using inquiry training learning model and conventional learning about the subject matter of elasticity and Hooke's law in High School. This type of research is a quasi-experimental with two groups of pretest-posttest design. The population of this research is all students of class XI MIPA in Public Senior High School 5 Medan. The sample was taken by a purposive sampling technique that consists of two groups, namely an experimental group and a control group. The data collected technique has been done by tests and observations activities SPS student. The data in this research was analyzed a hypothesis-testing t-test. The results showed significant differences in SPS between the application of using inquiry training learning models compared to conventional learning with the value of sig. was 0.000 at the significance of level 0.05 . Based on the results of the $\mathrm{N}$-Gain Score test with the application of the inquiry training learning model is higher in increasing SPS of the students by 0.70 in the high category compared to SPS of students with the application of conventional learning by 0.59 in the medium category.
\end{abstract}

Keywords: science process skills; inquiry training learning model.

\section{PENDAHULUAN}

Memasuki abad ke-21, Indonesia dihadapkan dengan berbagai permasalahan global ditandai dengan terjadinya persainganpersaingan di segala aspek kehidupan manusia yang menuntut pada perkembangan Sumber Daya Manusia (SDM) yang berkualitas baik dalam segi akademik maupun dalam pembentukkan karakternya. Salah satu faktor penting dalam mengembangkan kualitas SDM adalah pendidikan. Berbagai upaya yang telah dilakukan pemerintah untuk meningkatkan mutu pendidikan diberbagai jenjang pendidikan yaitu: pertama, penyempurnaan kurikulum dari Kurikulum Tingkat Satuan Pendidikan (KTSP) menjadi Kurikulum 2013 (K-13) mengalami perbaikan dan perubahan menjadi K-13 Revisi; kedua, pengalokasian anggaran pendidikan masih terus ditingkatkan; ketiga, peningkatan kompetensi guru melalui program sertifikasi guru; keempat, pengadaan dan perbaikan sarana dan prasarana sekolah melalui dana 
Bantuan Operasional Sekolah (BOS); kelima, pemerataan pendidikan melalui program Sarjana Mendidik di daerah Terdepan, Terluar, dan Tertinggal (SM-3T). Berbagai upaya telah pemerintah lakukan, namun fakta di lapangan belum menunjukkan hasil yang memuaskan.

Masalah utama pendidikan formal (sekolah), dewasa ini adalah rendahnya daya serap siswa yang ditandai dengan rendahnya perolehan rerataan nilai Ujian Nasional (UN) Fisika pada tiga tahun terakhir. Berdasarkan data statistik Pusat Penilaian (Kementerian Pendidikan dan Kebudayaan, 2019), hasil perolehan nilai UN Fisika di SMAN 5 Medan dari tahun ke tahun mengalami penurunan sejak berlakunya kebijakan pemerintah bahwa siswa dapat memilih salah satu mata pelajaran IPA pada tahun 2017 hingga 2019 dari setiap peserta UN, perolehan rerataan nilai UN Fisika yaitu menjadi 46,18 (372 peserta), 38,73 (398 peserta) dan 43,37 (455 peserta). Sementara berdasarkan hasil observasi awal dilakukan peneliti dengan menyebarkan angket pada 24 siswa kelas XI SMAN 5 Medan pada tahun 2018 diperoleh bahwa sebanyak 38\% siswa tidak menyukai pelajaran Fisika dan sebanyak 54\% siswa menganggap pelajaran Fisika itu sulit dan kurang menarik.

Sesuai dengan hasil UN dan observasi awal peneliti menunjukkan bahwa siswa masih mengalami kesulitan dalam memahami dan menguasai pelajaran Fisika ditandai dengan kurangnya rasa keingintahuan siswa dalam mempelajari Fisika, kebanyakan siswa yang ditemukan jarang melakukan aktifitas seperti memberikan pertanyaan/gagasan, mengulangi pembelajaran Fisika saat di rumah maupun melakukan eksperimen saat di sekolah. Dalam proses pembelajaran, siswa cenderung tidak mengetahui tujuan dan manfaat pelajaran Fisika dalam kehidupan sehari-hari.

Sementara berdasarkan wawancara yang dilakukan peneliti dengan salah satu guru Fisika di SMAN 5 Medan (2018), menyatakan bahwa dalam kegiatan pembelajaran beliau menerapkan pembelajaran aktif berdasarkan $\mathrm{K}-13$ di kelas, namun dalam pelaksaannya masih belum maksimal dalam menerapkan dan menguasai model pembelajaran dan Keterampilan Proses Sains (KPS). Siswa tidak terlibat langsung saat kegiatan pembelajaran sedang berlangsung, sehingga KPS siswa menjadi terhambat dan mengganggu proses pembelajaran di kelas. Berdasarkan fakta di lapangan menunjukkan siswa masih belum terbiasa dalam mengajukan pertanyaan/ide, dan siswa masih mengalami kesulitan dalam merumuskan hipotesis dan prediksi. Selain itu, siswa cenderung tidak mampu menyelesaikan masalah berhubungan dengan konsep Fisika, namun menyelesaikan masalah berhubungan dengan rumus/hitungan. Untuk itu, pentingnya mengenalkan dan melibatkan siswa secara langsung dengan menerapkan keterampilan proses berbasis sains, diharapkan mampu menekankan kemampuan untuk menemukan pengetahuannya melalui pengalaman belajar, hukum, prinsip, dan generalisasi, yang dapat berpeluang mengembangan keterampilan berpikir tingkat tinggi.

Pembelajaran Fisika secara ideal dilaksanakan dengan menggunakan metode inkuiri untuk menciptakan kemampuan berpikir, bekerja dan berperilaku secara ilmiah. Oleh karena itu, pembelajaran Fisika melacak keterampilan ilmiah berkaitan dengan produk ilmiah, proses ilmiah dan sikap ilmiah yang digunakan untuk mengungkapkan prosedur, proses, dan metode yang dianggap penting digunakan para ilmuwan saat membangun ilmu pengetahuan dan memecahkan masalah yang bersifat eksperimen (Kustijono et al., 2018). KPS telah memberikan kesempatan berharga bagi semua orang untuk membangun pengetahuannya sendiri melalui penyelidikan ilmiah (Duruk et al., 2017). KPS membantu siswa dalam mengembangkan perspektifnya dalam IPA menjadi lebih ilmiah (Elmas et al., 2018). KPS secara umum berpengaruh positif pada pengajaran sains, aktivitas pembelajaran di kelas dapat memajukan pembelajaran konseptual, dan dapat diperoleh secara efektif melalui kegiatan laboratorium di mana guru dan siswa terlibat (Gultepe, 2016). Menurut Nasional Science Teacher Association, KPS merupakan seperangkat keterampilan yang digunakan para ilmuwan dalam melakukan penyelidikan ilmiah yang harus dikuasai oleh siswa (Prajoko et al., 2017). Menurut Duruk et al. (2017), KPS terdiri dari KPS dasar (mengamati, mengklasifikasikan, memprediksi, mengukur, mengomunikasikan,menyimpulkan) dan KPS terinintegrasi (menafsirkan data, merumuskan hipotesis, mengontrol variabel, bereksperimen, mendefinisikan operasional dan pemodelan.

Berdasarkan hasil observasi tersebut, perlunya pemecahan masalah yaitu dengan cara meningkatkan KPS siswa selama proses pembelajaran Fisika berlangsung. Salah satu model pembelajaran yang dapat mendukung siswa dalam meningkatkan KPSnya adalah model pembelajaran inquiry training. Model ini didefinisikan sebagai model yang dirancang untuk membawa siswa secara langsung kedalam proses ilmiah melalui latihan-latihan yang dapat memadatkan proses ilmiah kedalam periode waktu yang singkat. Model ini menawarkan strategi-strategi penelitian, nilainilai dan sikap penting dalam ranah penelitian 
terkait keterampilan proses (Joyce et al., 2015), diperkuat berdasarkan hasil penelitian sebelumnya menunjukkan bahwa kemampuan kognitif Fisika dan KPS siswa menggunakan model pembelajaran scientific inquiry berbasis perubahan konseptual lebih baik dibandingkan pembelajaran konvensional (Sahyar \& Nasution, 2017). Kemampuan pemecahan masalah dengan model pembelajaran inquiry training berbasis Just In Time Teaching (JITT), lebih tinggi dibandingkan model pembelajaran kooperatif (Turnip et al., 2016). Selain itu, Model pembelajaran inquiry training lebih berpengaruh dalam meningkatkan KPS siswa daripada pembelajaran konvensional (Hakim \& Aisyah, 2016).

Berdasarkan hasil penelitian Aktamiş et al. (2016) menunjukkan bahwa pendidikan sains berbasis penyelidikan memiliki tingkat pengaruh akademik siswa yang positif dan lebih tinggi, metode pengajaran dan pembelajaran memiliki tingkat pengaruh positif dan menengah terhadap KPS dan sikap terhadap sains. Sementara hasil penelitian Hardianti \& Kuswanto (2017) menunjukkan adanya perbedaan efektifitas yang signifikan diantara tingkat 2, 3 dan 4 pada pembelajaran inquiry dalam meningkatkan KPS siswa khususnya pada Inquiry Learning of Level 3 (ILL-3) lebih efektif dalam meningkatkan KPS. Selain itu, model pembelajaran inquiry training menggunakan macromedia flash lebih baik daripada pembelajaran konvensional dalam meningkatkan KPS siswa, KPS pada kelompok siswa yang memiliki kemampuan berpikir kreatif tinggi lebih baik daripada kelompok siswa dengan kemampuan berpikir kreatif rendah, serta terdapat interaksi antara model pembelajaran inquiry training menggunakan macromedia flash dengan kemampuan berpikir kreatif dalam mempengaruhi KPS siswa (Siagian et al., 2016).

Berdasarkan uraian masalah di atas, peneliti tertarik melakukan penelitian berjudul Perbedaan Keterampilan Proses Sains (KPS) Siswa Menggunakan Model Pembelajaran Inquiry Training dan Pembelajaran Konvensional Pada Materi Pokok Elastisitas dan Hukum Hooke di SMA. Penelitian ini bertujuan untuk mengetahui ada perbedaan KPS siswa menggunakan model pembelajaran inquiry training dan pembelajaran konvensional dan untuk mengetahui model pembelajaran inquiry training lebih tinggi dalam meningkatkan KPS siswa dibandingkan dengan pembelajaran konvensional.

\section{METODE PENELITIAN}

Penelitian bersifat quasi experiment bertujuan untuk mengetahui ada atau tidaknya pengaruh model pembelajaran inquiry training terhadap KPS siswa. Desain penelitian yang digunakan adalah two group pretest-posttest design. Populasi penelitian ini adalah seluruh siswa kelas XI MIPA SMAN 5 Medan dan pengambilan sampel dilakukan dengan teknik purposive sampling yang terdiri dari dua kelas yaitu kelas eksperimen menggunakan model pembelajaran inquiry training dan kelas kontrol menggunakan pembelajaran konvensional yang masing-masing berjumlah 30 orang siswa.

Pengumpulan data dalam penelitian ini, diperoleh melalui pemberian tes KPS (pretestposttest) yang telah divalidkan sebanyak 9 butir soal berbentuk essay dan observasi selama proses pembelajaran berlangsung menggunakan lembar observasi aktivitas KPS siswa. Kemudian, data dianalisis dengan pengujian hipotesis uji t dan uji $\mathrm{N}$-Gain Score (NGS) dengan bantuan program SPSS 25. Sebelumnya dilakukan pengolahan data sampel, ditabulasi dan data dianalisis dengan uji normalitas (data yang digunakan harus berdistribusi normal) dan uji homogenitas (data harus memiliki varians populasi yang homogen) sebagai prasyarat dari pengujian hipotesis uji t. Bagan penelitian ini ditunjukkan pada Gambar 1.

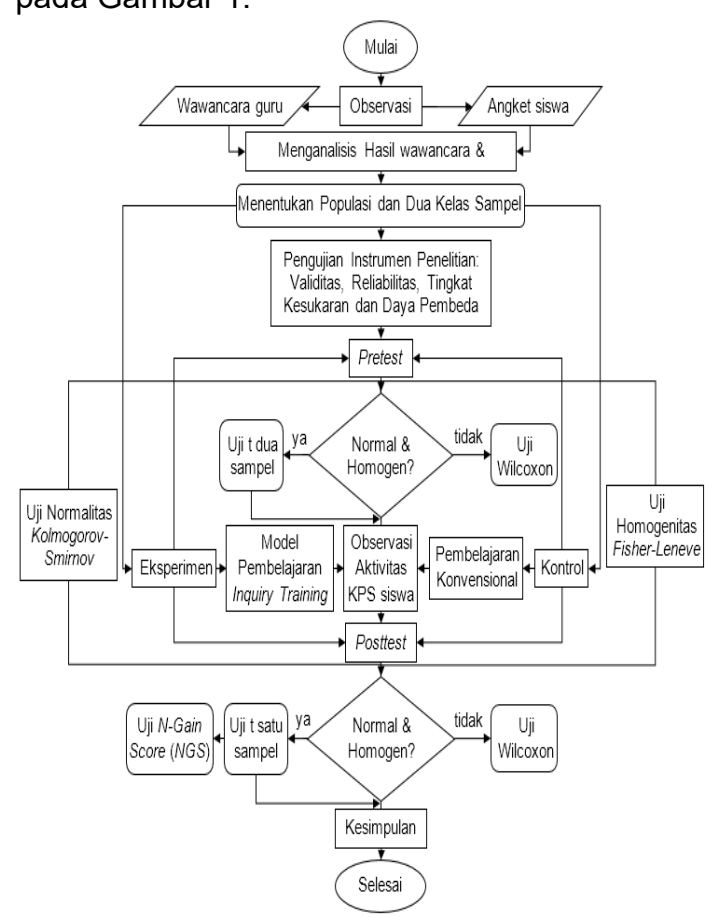

Gambar 1. Bagan Penelitian Sederhana

\section{HASIL DAN PEMBAHASAN Hasil Penelitian}

Data yang dideskripsikan dalam penelitian ini meliputi distribusi frekuensi data pretest (Gambar 2 dan Gambar 3) dan posttest siswa (Gambar 4 dan Gambar 5). Berdasarkan 
perolehan hasil rata-rata nilai pretest pada masing-masing kelas tidak jauh berbeda yakni 32,59 dan 30,67. Sementara, perolehan hasil rata-rata nilai posttest pada masing-masing kelas mengalami peningkatan yakni 79,85 dan 71,33 (Gambar 6) menunjukkan bahwa KPS siswa pada kelas eksperimen lebih tinggi dibandingkan kelas kontrol. Kemudian, data dianalisis dengan uji normalitas KolmogorovSmirnov dan uji homogenitas Fisher-Leneve diperoleh nilai sig. untuk data pretest-posttest di kelas eksperimen dan kontrol pada taraf signifikan 0,05 menunjukkan bahwa data berdistribusi normal dan homogen sebagai prasyarat pengujian hipotesis uji t.

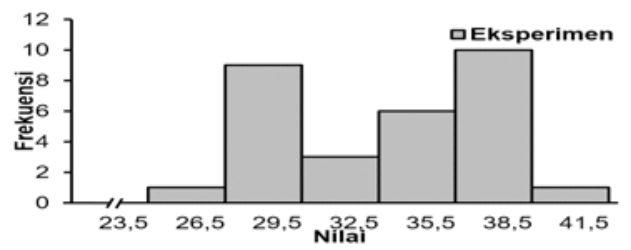

Gambar 2. Histogram Nilai Pretest Kelas Eksperimen

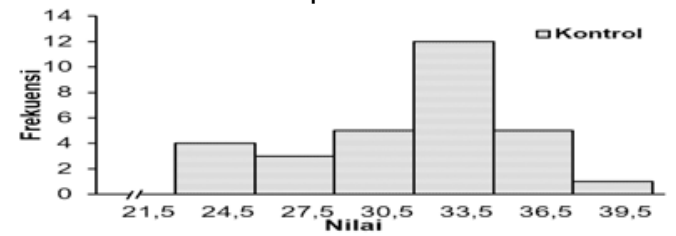

Gambar 3. Histogram Nilai Pretest Kelas Kontrol

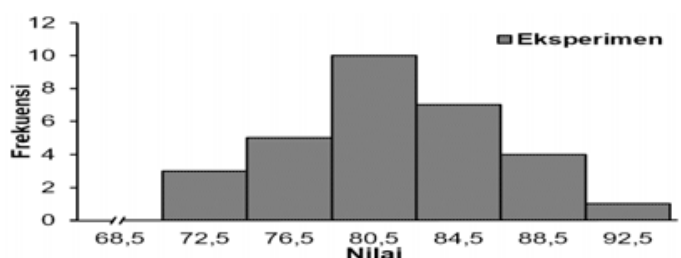

Gambar 4. Histogram Nilai Posttest Kelas Eksperimen

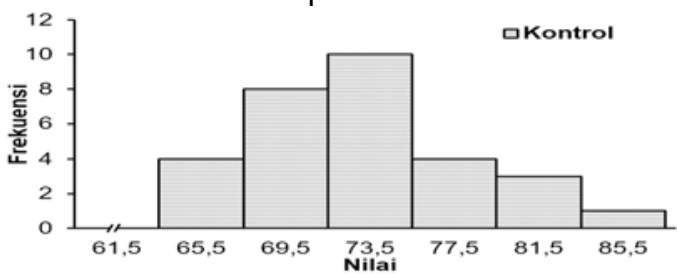

Gambar 5. Histogram Nilai Posttest Kelas Kontrol

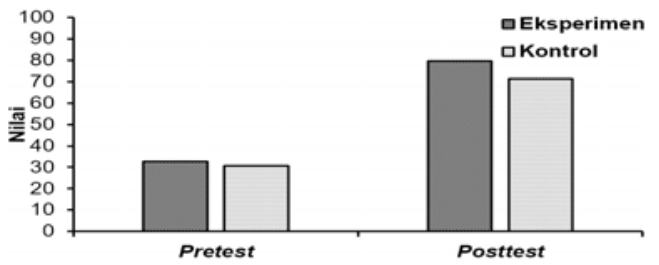

Gambar 6. Diagram Batang Nilai Rata-Rata Kelas Eksperimen dan Kelas Kontrol
Selanjutnya dilakukan pengujian hipotesis uji t dengan menggunakan uji independent Sample T-Test dengan bantuan program SPSS 25. Berdasarkan hasil pengujian Hipotesis uji t dua sampel diperoleh nilai sig. yaitu 0,077 dengan taraf signifikan $0,05\left(\mathrm{H}_{\mathrm{o}}\right.$ diterima $\mathrm{H}_{\mathrm{a}}$ ditolak), maka dapat disimpulkan bahwa kemampuan awal siswa di kelas eksperimen dan kontrol adalah sama (tidak terdapat perbedaan yang signifikan antara rata-rata nilai pretest kelas eksperimen dan kontrol) seperti ditunjukkan pada Tabel 1.

Tabel 1. Hasil Uji Hipotesis Data Pretest

\begin{tabular}{|c|c|c|c|c|c|c|c|}
\hline \multirow[t]{2}{*}{ Data } & \multirow[t]{2}{*}{ Kelas } & \multicolumn{2}{|c|}{$\begin{array}{l}\text { Levene'sTest } \\
\text { for Equality } \\
\text { of Variances }\end{array}$} & \multicolumn{3}{|c|}{$\begin{array}{c}\text { t-test for } \\
\text { Equality of } \\
\text { Means }\end{array}$} & \multirow[t]{2}{*}{ Kesimpulan } \\
\hline & & $\boldsymbol{F}$ & Sig. & $T$ & $D f$ & $\begin{array}{l}\text { Sig.(2- } \\
\text { tailed) }\end{array}$ & \\
\hline Pretest & $\begin{array}{c}\text { Eksperimen } \\
\text { \& Kontrol }\end{array}$ & 0,626 & 0,432 & 1,801 & 58 & 0,077 & $\mathrm{H}_{0}$ diterima \\
\hline
\end{tabular}

Setelah, kelas kedua kelas diberikan perlakuan yang berbeda dengan model inquiry training (kelas eksperimen) dan pembelajaran konvensional (kelas kontrol). Berdasarkan hasil pengujian hipotesis uji $t$ satu sampel diperoleh nilai sig. yaitu 0,000 pada taraf signifikan $0,05\left(\mathrm{H}_{\circ}\right.$ ditolak $\mathrm{H}_{\mathrm{a}}$ diterima), maka dapat disimpulkan bahwa adanya perbedaan KPS siswa menerapkan model pembelajaran inquiry training dengan KPS siswa yang menerapkan pembelajaran konvensional, sehingga model pembelajaran inquiry training dapat dikatakan memberikan efek terhadap KPS siswa pada materi elastisitas dan hukum Hooke di kelas XI semester I SMAN 5 Medan seperti ditunjukkan pada Tabel 2.

Tabel 2. Hasil Uji Hipotesis Data Posttest

\begin{tabular}{|c|c|c|c|c|c|c|c|}
\hline \multirow[t]{2}{*}{ Data } & \multirow[t]{2}{*}{ Kelas } & \multicolumn{2}{|c|}{$\begin{array}{l}\text { Levene'sTest } \\
\text { for Equality } \\
\text { of Variances }\end{array}$} & \multicolumn{3}{|c|}{$\begin{array}{c}\text { t-test for } \\
\text { Equality of } \\
\text { Means }\end{array}$} & \multirow[t]{2}{*}{ Kesimpulan } \\
\hline & & $F$ & Sig. & $T$ & dff & $\begin{array}{l}\text { Sig.(2- } \\
\text { tailed) }\end{array}$ & \\
\hline Posttes & $\begin{array}{l}\text { Eksperimen } \\
\text { dan Kontrol }\end{array}$ & 0,384 & 0,538 & 6,703 & 58 & 0,000 & $\mathrm{H}_{\mathrm{a}}$ diterima \\
\hline
\end{tabular}

Dalam upaya perolehan peningkatan KPS siswa untuk menguasai konsep melalui pemberian tes sebelum dan sesudah diberikan perlakuan pembelajaran dengan menerapkan model pembelajaran inquiry training dan konvensional dilakukan uji N-Gain Score(NGS) di kelas eksperimen yaitu 0,70 dalam kategoi tinggi dan pada kelas kontrol yaitu 0,59 dalam kategori sedang yang menunjukkan penerapan model pembelajaran inquiry training lebih tinggi dalam meningkatkan KPS siswa dibandingkan 
pembelajaran konvensional seperti ditunjukkan pada Gambar 7.

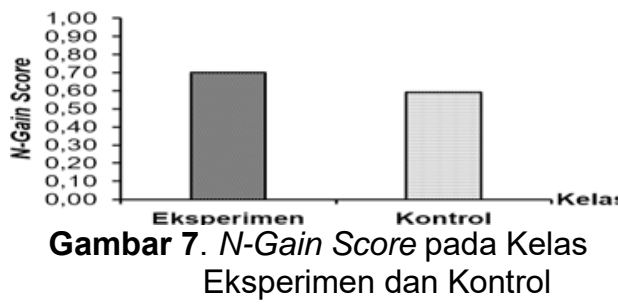

Hasil penelitian ini juga menunjukkan aktivitas siswa selama proses pembelajaran dapat meningkatkan KPS siswa yang diperoleh melalui hasil peningkatan rerataan aktivitas siswa dalam mengamati (KPS-1), merumuskan hipotesis (KPS-2), memprediksi (KPS-3), menemukan pola dan hubungan (KPS-4), mengomunikasikan secara efektif (KPS-5), merancang dan membuat percobaan (KPS-6), serta mengukur dan menghitung (KPS-7) di kelas eksperimen dan kontrol pada setiap pertemuan yang dapat dilihat pada Gambar 8 dan Gambar 9. Perkembangan aktivitas KPS siswa di kelas eksperimen dan kontrol seperti yang ditunjukkan pada Gambar 10.

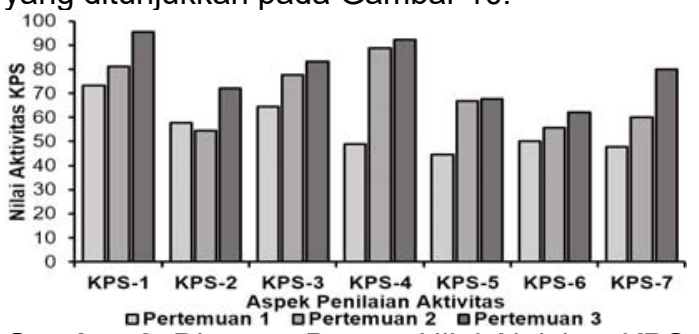

Gambar 8. Diagram Batang Nilai Aktivitas KPS Siswa di Kelas Eksperimen

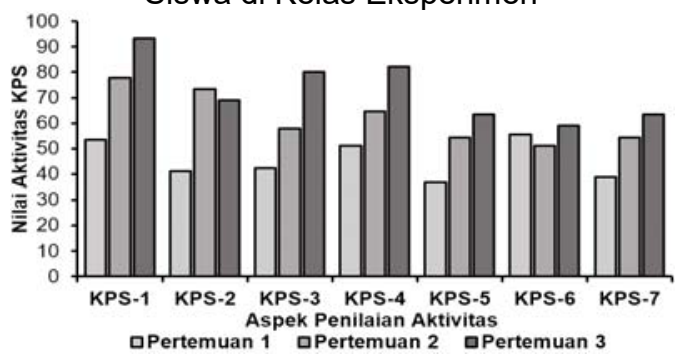

Gambar 9. Diagram Batang Nilai Aktivitas KPS Siswa di Kelas Kontrol

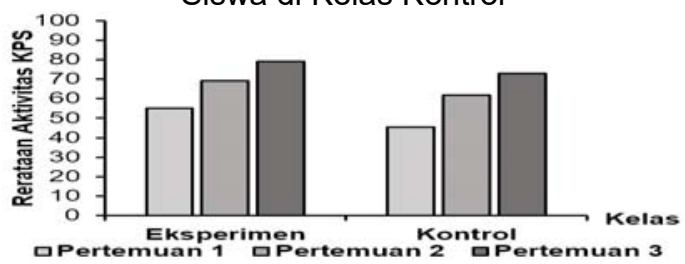

Gambar 10. Diagram Batang Perkembangan Aktivitas KPS Siswa

\section{Pembahasan}

Berdasarkan hasil analisis data, model pembelajaran inquiry training dan konvensional mempengaruhi KPS yang menunjukkan bahwa kemampuan awal pada kelas eksperimen dan kontrol tidak jauh berbeda/sama diperoleh melalui hasil nilai rata-rata pretest KPS siswa pada kelas eksperimen dan kontrol masingmasing yaitu 32,59 dan 30,67 . Hasil rata-rata nilai posttest KPS siswa setelah diberikan perlakuan berbeda, siswa di kelas eksperimen diajarkan dengan model pembelajaran inquiry training dan siswa di kelas kontrol diajarkan dengan pembelajaran konvensional masingmasing yaitu 79,85 dan 71,33 . Hasil penelitian ini sejalan dengan penelitian Turnip et al. (2016), yang menunjukkan adanya perbedaan kemampuan pemecahan masalah Fisika pada mahasiswa yang diajarkan dengan model pembelajaran inquiry training berbasis JITT dan model pembelajaran kooperatif pada pembelajaran Fisika Umum II. Berdasarkan hasil pengujian hipotesis data diperoleh bahwa $F=55,729$ dan sig. $=0,000\left(\mathrm{H}_{\mathrm{a}}\right.$ diterima dan $\mathrm{H}_{\mathrm{o}}$ ditolak). Penelitian ini juga sejalan dengan penelitian Sihaloho et al. (2017) menunjukkan adanya pengaruh model pembelajaran inquiry training dan konvensional terhadap KPS dan hasil belajar siswa. KPS dan hasil belajar siswa yang menerapkan model pembelajaran inquiry training lebih baik dibandingkan dengan konvensional. Selain itu, KPS siswa yang diajarkan dengan model pembelajaran inquiry training lebih baik dibandingan konvensional (Aminah \& Derlina, 2015; Harahap et al., 2016; Mahulae et al., 2017).

Observasi aktivitas siswa selama proses pembelajaran baik di kelas maupun di laboratorium dinilai berdasarkan indikator KPS. Perkembangan aktivitas siswa diperoleh dari peningkatan rata-rata aktivitas siswa selama diberikan perlakuan dari pertemuan I, II dan III pada kelas eksperimen masing-masing yaitu $54,42,69,21$ dan 79,05. Sementara rata-rata aktivitas siswa kelas kontrol dari pertemuan I, II, dan III masing-masing yaitu 45,56, 61,90, dan 72,86 menunjukkan bahwa aktivitas siswa mengalami peningkatan KPS siswa selama proses pembelajaran baik di kelas eksperimen maupun di kelas kontrol. Penelitian ini sejalan dengan penelitian Hakim \& Aisyah (2016) yang menunjukkan model inquiry training lebih berpengaruh dalam meningkatkan KPS siswa dibandingkan pembelajaran konvensional yang diperkuat dengan adanya peningkatan KPS berdasarkan perolehan rata-rata nilai pretest pada kelas eksperimen dan kontrol masingmasing yakni 32,59 dan 30,67. Sementara rata-rata nilai posttest pada kelas eksperimen dan kontrol masing-masing yakni 79,85 dan 
71,33. Dengan NGS pada kelas eksperimen yaitu 0,70 lebih tinggi dari NGS pada kelas kontrol yaitu 0,59 , sejalan dengan penelitian Hardianti \& Kuswanto (2017) menunjukkan adanya perbedaan efektifitas yang signifikan diantara level 2, 3 dan 4 pada Inquiry Learning Level (ILL) dalam meningkatkan KPS siswa dibuktikan pada ILL-3 (NGS=0,69) lebih tinggi dari ILL-4 (NGS=0,38) dan ILL-2 (NGS=0,58). Selain itu, adanya peningkatan rata-rata dari keseluruhan aktivitas belajar dari pertemuan I - III di kelas eksperimen dan kontrol masingmasing yakni 67,83 (kategori cukup terampil) dan 60,11 (kategori kurang terampil).

Pada awal pembelajaran siswa diberi permasalahan nyata yang akan memotivasi siswa seperti "Pada saat menarik sebuah karet gelang, apakah karet tersebut mengalami perubahan bentuk? Demikian juga jika anda duduk di atas sebuah kasur springbed maupun kasur yang berisi kapas, apakah kedua kasur tersebut akan mengalami perubahan bentuk? Mengapa hal tersebut bisa terjadi?" dengan permasalahan tersebut siswa tertarik untuk menyelidiki permasalahan yang berhubungan dalam kehidupan sehari-hari, setiap siswa juga akan secara realistis memikirkan jawabannya masing-masing, sehingga jawaban ditemukan akan tersimpan dalam jangka waktu yang panjang dalam memori siswa. Siswa secara berkelompok mencoba menemukan jawaban dari permasalahan tersebut, sehingga mereka dapat bertukar pendapat antara satu sama lain. Selanjutnya, siswa melakukan eksperimen untuk membuktikan jawaban sementara yang telah ditentukan dengan kelompoknya masingmasing, melakukan penyelidikan dan saling berdiskusi bersama-sama dalam mengerjakan LKPD serta bertanya pada guru jika mereka mengalami kesulitan. Fase ini termasuk fase yang paling disukai siswa disebabkan mereka merasa sangat antusias dan keingintahuan mereka dalam melakukan penyelidikan melalui eksperimen yang menyebabkan suasana kelas menjadi lebih aktif serta memotivasi siswa dalam mengembangkan KPSnya. Siswa saling berdiskusi dalam melakukan penyelidikan dan berbagi tugas sehingga setiap anggota secara berurutan melakukan percobaan.

Setelah mengumpulkan data, fase selanjutnya yaitu mengolah dan memformulasi suatu penjelasan dimana siswa mengolah dan menganalisis data percobaan yang diperoleh kemudian merencanakan bagaimana hasil data yang diperoleh dapat disajikan semenarik mungkin untuk dipresentasikan di depan kelas. Setiap kelompok memiliki kesempatan yang sama dalam memberikan pendapat/argumen kepada kelompok yang mempresentasikan hasil diskusinya. Tugas guru dalam tahap ini mengarahkan dan membimbing siswa dalam memperbaiki jawaban siswa yang kurang tepat dan menguatkan jawaban siswa yang benar kepada kelompok yang bertanya, serta guru juga mengevaluasi hasil persentasi dan yang disampaikan oleh setiap kelompok. Fase terakhir yaitu analisis proses penelitian, peneliti dan siswa merangkum materi pembelajaran.

Penelitian ini sejalan dengan pendapat (Joyce et al., 2015), model inquiry training melibatkan siswa secara langsung dalam masalah penelitian yang benar-benar orisinil dengan menghadapkan siswa pada bidang investigasi, membantu siswa mengidentifikasi masalah konseptual antar metodologi dalam suatu bidang dan mengajak siswa merancang serta memecahkan masalah. Penggunaan model pembelajaran inquiry training selama proses pembelajaran tentunya memiliki pengaruh dan dampak yang baik terhadap kemampuan siswa. Menurut Gultepe (2016) KPS berpengaruh positif dalam pengajaran sains dan aktivitas pembelajaran di kelas yang mempromosikan pembelajaran konseptual yang secara efektif hanya dapat diperoleh melalui kegiatan laboratorium dimana guru dan siswa terlibat. Menurut Şen \& Vekli (2016) dalam penelitiannya menunjukkan adanya pengaruh yang positif dari pendekatan yang menggunakan pembelajaran berbasis inquiry terhadap KPS dan tingkat persepsi self-eficacy, penggunaan laboratorium dari guru sains praservis diperoleh berdasarkan hasil pemikiran positif terhadap keefektifan positif dari pendekatan pembelajaran berbasis inquiry dalam wawancara.

Walaupun penggunaan model inquiry training lebih baik dalam meningkatkan KPS siswa daripada konvensional, namun masih terdapat beberapa kendala dalam pelaksanaan penelitian yaitu peneliti belum maksimal dalam memanajemen waktu dengan baik selama proses pembelajaran berlangsung terutama saat proses penyelidikan dan presentasi hasil penyelidikan tidak berjalan sesuai dengan direncanakan; pembelajaran menggunakan model inquiry training menuntut siswa untuk merancang percobaan memakan waktu yang cukup lama walaupun sudah dibantu oleh peneliti karena siswa belum pernah melakukan praktikum tersebut; pernyajian masalah dalam LKPS kurang mengunggah rasa ingin tahu siswa sehingga siswa kurang termotivasi dalam menyelesaikan masalah.

\section{SIMPULAN DAN SARAN}

Berdasarkan hasil analisis data dan pembahasan dapat disimpulkan bahwa terdapat perbedaan KPS siswa yang diajarkan dengan model pembelajaran inquiry training dan 
pembelajaran konvensional diperoleh dari hasil uji t satu sampel menggunakan independent sample t-test dengan bantuan program SPSS 25 diperoleh nilai sig. yaitu 0,000 pada taraf signifikan 0,05 . Model pembelajaran inquiry training lebih tinggi dalam meningkatkan KPS siswa diperoleh melalui hasil uji $N$-Gain Score (NGS) pada kelas eksperimen adalah 0,70 dalam kategori tinggi sedangkan pada kelas kontrol adalah 0,59 dalam kategori sedang.

Adapun saran yang diberikan peneliti, memperbaiki kualitas pembelajaran dengan menyajikan permasalahan yang dihadapkan pada situasi/peristiwa yang tak terduga terjadi secara menakjubkan dan bersifat up to date yang dapat mengunggah rasa keingintahuan dan memotivasi siswa dalam menyelesaikan permasalahan. Dalam pelaksanaannya, perlu mempertimbangkan dan memperhitungkan alokasi waktu dan merancang percobaan yang dapat merangsang siswa untuk melakukan penyelidikan ketika bereksperimen yang menuntut siswa agar lebih aktif dalam proses pembelajaran sehingga kegiatan pembelajaran dapat berjalan sesuai dengan yang diinginkan. Selain itu, pentingnya membuat perencanaan dalam mempersiapkan alat dan bahan yang digunakan, dan dapat mengkondusifkan kelas pada saat pembelajaran berlangsung dengan cara lebih tegas dalam mengarahkan siswa.

\section{DAFTAR RUJUKAN}

Aktamiş, H., Hiğde, E., \& Özden, B. (2016). Effects of the inquiry-based learning method on students' achievement, science process skills and attitudes towards science: A meta-analysis science. Journal of Turkish Science Education. https://doi.org/10.12973/tused.10183a

Aminah, S., \& Derlina. (2015). THE EFFECT OF INQUIRY TRAINING LEARNING MODEL AND THE LOGICAL THINKING ABILITY ON SCIENCE PROCESS SKILL OF STUDENTS. Jurnal Pendidikan Fisika. https://doi.org/10.22611/jpf.v4i2.3240

Duruk, U., Akgün, A., Dogan, C., \& Gülsuyu, F. (2017). Examining the Learning Outcomes Included in the Turkish Science Curriculum in Terms of Science Process Skills: A Document Analysis with Standards-Based Assessment. International Journal of Environmental and Science Education.

Elmas, R., Border, G. M., Aydogdu, B., \& Saban, Y. (2018). The Inclusion of Science Process Skills in Multiple Choice Question: Are We Getting Any Better? European Journal of Science and Mathematics Ducation, 6(1), 1323.

Gultepe, N. (2016). High school science teachers' views on science process skills. International Journal of Environmental and Science Education. https://doi.org/10.12973/ijese.2016.348 a

Hakim, A., \& Aisyah. (2016). Pengaruh Model Pembelajaran Inquiry Traning Terhadap Keterampilan Proses Sains pada Pelajaran Fisika. Jurnal Pendidikan Fisika, 5(2), 69-74.

Harahap, M. B., Manurung, S. R., Marbun, M. A., \& Mihardi, S. (2016). Effect Model Inquiry Training On Students Science Process Skill. Advances in Social Sciences Research Journal. https://doi.org/10.14738/assrj.311.2288

Hardianti, T., \& Kuswanto, H. (2017). Difference among levels of inquiry: Process skills improvement at senior high school in Indonesia. International Journal of Instruction. https://doi.org/10.12973/iji.2017.1028a

Joyce, B. R., Weil, M., \& Calhoun, E. (2015). Models of Teaching (9th ed.). Pearson Education, Inc.

Kementerian Pendidikan dan Kebudayaan. (2019). Laporan Hasil Ujian Nasional. Pusat Penilaian PendidikanKementerian Pendidikan Dan Kebudayaan.

Kustijono, R., Jatmiko, B., \& Ibrahim, M. (2018). The effect of scientific attitudes toward science process skills in basic physics practicum by using peer model. International Journal of GEOMATE. https://doi.org/10.21660/2018.50.IJCS T50

Mahulae, P. S., Sirait, M., \& Sirait, M. (2017). The Effect of Inquiry Training Learning Model Using PhET Media and Scientific Attitude on Students' Science Process Skills. IOSR Journal of Research \& Method in Education. https://doi.org/10.9790/73880705012429

Prajoko, S., Amin, M., Rohman, F., \& Gipayana, M. (2017). ERIC - The Usage of Recycle Materials for Science Practicum: Is There Any Effect on Science Process Skills?, International Journal of Evaluation and Research in Education, 2017-Mar. International Journal of Evaluation and Research in Education, v6 N1 P1-8 Mar 2017.

Sahyar, \& Nasution, F. H. (2017). The Effect of Scientific Inquiry Learning Model 
Based on Conceptual Change on Physics Cognitive Competence and Science Process Skill (SPS) of Students at Senior High School. Journal of Education and Practice, 8(5), 120-126.

ŞEN, C., \& VEKLİ, G. S. (2016). The Impact of Inquiry Based Instruction on Science Process Skills and Self-efficacy Perceptions of Pre-service Science Teachers at a University Level Biology Laboratory. Universal Journal of Educational Research. https://doi.org/10.13189/ujer.2016.040 319

Siagian, H. E., Bukit, N., \& Derlina. (2016). Efek Model Inquiry Training Menggunakan Media Macroflash dan Kemampuan Berpikir Kreatif Terhadap Keterampilan Proses Sains. Jurnal Pendidikan Fisika, 5(1), 19-25.

Sihaloho, H. W., Sahyar, \& Mariati, P. S. (2017). The Effect of Inquiry Training Learning Model on Science Process Skills and Student Learning Outcomes. Journal of Research \& Method in Education.

https://doi.org/10.22611/jpf.v4i2.3240

Turnip, B., Wahyuni, I., \& Tanjung, Y. I. (2016). The Effect of Inquiry Training Learning Model Based on Just in Time Teaching for Problem Solving Skill Betty. Journal of Education and Practice. 